\title{
PENGEMBANGAN MODEL PEMBELAJARAN HUMANIS RELIGIUS DALAM PENDIDIKAN KARAKTER DI SEKOLAH DASAR
}

\author{
${ }^{1)}$ Jumarudin, ${ }^{2)}$ Abdul Gafur, ${ }^{3)}$ Siti Partini Suardiman \\ SD Baturetno Banguntapan Bantul, ${ }^{2,3)}$ Universitas Negeri Yogyakarta \\ jumarudinudin@yahoo.co.id, agafur68@gmail.com
}

\begin{abstract}
Abstrak
Tujuan penelitian ini adalah untuk mengetahui; (1) pengembangan pendekatan pembelajaran humanis yang dapat mewujudkan tujuan pendidikan karakter di sekolah dasar (SD); (2) penerapan model pembelajaran humanis religius dalam pendidikan karakter di SD; (3) keefektifan model pembelajaran humanis religius dalam menanamkan nilai-nilai karakter dalam diri peserta didik di SD; dan (4) tanggapan peserta didik terhadap model pembelajaran humanis religius dalam pendidikan karakter di $S D$. Penelitian ini merupakan penelitian pengembangan. Subjek coba dalam penelitian ini adalah kelas $V$ pada tiga SDN yang terdapat di Kecamatan Banguntapan, Kabupaten Bantul, yaitu SD Jomblangan, $S D$ Baturetno, dan SD Jaranan. Analisis data dilakukan dengan pendekatan deskriptif kualitatif dan pendekatan kuantitatif. Hasil penelitian menunjukkan bahwa: (1) pengembangan model diawali dengan studi pendahuluan, studi pengembangan, dan implementasi yang kemudian menghasilkan perangkat model pembelajaran humanis dalam pendidikan karakter di SD, (2) model humanis religius dalam pendidikan karakter di SD menunjukkan tingkat keterlaksanaan yang baik, memenuhi kriteria sangat efektif, sangat praktis, dan valid karena disusun berdasarkan landasan berpikir yang rasional dengan teori pendukung yang kuat dan relevan, (3) model pembelajaran humanis religius dalam pendidikan karakter yang dikembangkan efektif untuk digunakan dalam pendidikan karakter di SD, dan (4) peserta didik memiliki respon yang sangat positif terhadap model pembelajaran humanis religius dalam pendidikan karakter di SD.
\end{abstract}

Kata kunci: model pembelajaran humanis religius, pendidikan karakter, sekolah dasar

\section{DEVELOPING A HUMANIST-RELIGIOUS LEARNING MODEL FOR CHARACTER BUILDING IN ELEMENTARY SCHOOLS}

\author{
${ }^{1)}$ Jumarudin, ${ }^{2)}$ Abdul Gafur, ${ }^{3)}$ Siti Partini Suardiman \\ SD Baturetno Banguntapan Bantul, ${ }^{2,3)}$ Universitas Negeri Yogyakarta \\ jumarudinudin@yahoo.co.id, agafur68@gmail.com
}

\begin{abstract}
This study aims to examine: (1) the development of humanist-religious learning approaches that can realize the objectives of character building at the elementary-school level, (2) the implementation of the humanist-religious learning model for character building in elementary schools, (3) the effectiveness of the humanist-religious learning model in instilling character values in elementary-school students, and (4) students' responses to the humanist-religious learning model for character building in elementary schools. This was a research \& development $(R \& D)$ study. The subjects of this study consisted of class $V$ students at 3 state elementary schools (SD Negeri) located in Banguntapan District of Bantul Regency, namely SD Jomblangan, SD Baturetno, and SD Jaranan. The data analysis was performed using descriptive-qualitative approaches and quantitative approaches. The results suggest that: (1) the development of the model began with a preliminary study, a development study, and implementation that later resulted in the humanist learning model for character building in elementary schools, (2) the humanist-religious model for character building in elementary schools indicated a good level of implementation, met the very effective criteria, was highly practical, and valid as it was arranged using the foundation of rational thinking with strong and relevant supporting theories, (3) the developed humanist-religious learning model for character building was effective to be implemented in character building in elementary schools, and (4) the students provided significantly positive responses to the humanist-religious learning model for character building in elementary schools.
\end{abstract}

Keywords: the humanist-religious learning model, character building, elementary schools 


\section{PENDAHULUAN}

Revitalisasi terhadap pendidikan karakter memang telah dicanangkan oleh Kementrian Pendidikan Nasional (Kemdiknas) Republik Indonesia mulai tahun 2011. Banyak satuan pendidikan yang telah melakukan revitaliasi pendidikan karakter. Berbagai seminar pendidikan karakter diadakan di tingkat nasional maupun di daerah. Seminar-seminar tersebut telah diikuti oleh praktisi pendidikan. Pada tahun 2011, Kemdiknas telah mengeluarkan buku Panduan Pendidikan Karakter yang kemudian disosialisasikan pada satuan pendidikan di berbagai daerah. Namun demikian, belum banyak praktisi pendidikan yang menggunakan dan mengaplikasikan buku panduan tersebut dalam pelaksanaan pembelajaran. Hal ini dapat diketahui dari belum terlaksananya pendidikan karakter sebagaimana yang diharapkan.

Sampai dengan saat ini, pendidikan karakter belum terlaksana sebagaimana yang diharapkan (Albertus, 2009, p.127). Sebagai praktisi pendidikan, sudah banyak guru yang berencana menerapkan pendidikan karakter dengan memasukkan nilai-nilai karakter pada RPP. Namun dalam pelaksanaan pembelajaran, nilai-nilai karakter tersebut tidak menjadi perhatian. Rencana pembelajaran yang telah disusun seringkali tidak terlaksana sebagaimana mestinya.

Masih banyak guru yang merasa bahwa pendidikan karakter sulit untuk diterapkan dan membutuhkan alokasi waktu yang lebih banyak. Selain itu, guru juga menganggap bahwa pendidikan karakter menuntut guru untuk meluangkan lebih banyak waktu untuk menyusun bahan ajar, mencari media pembelajaran yang tepat, dan lain sebagainya. Dengan kata lain, masih banyak guru yang berpandangan bahwa pendidikan karakter sulit untuk dilaksanakan karena membutuhkan waktu dan perhatian ekstra, sedangkan guru memiliki waktu yang terbatas (Triatmanto, 2010, p.199). Seharusnya, guru memiliki manajemen waktu yang lebih baik dalam mengajar maupun dalam merencanakan pembelajaran sehingga dapat menerapkan pendidikan karakter.

Pendidikan karakter melalui pembelajaran yang humanis religius perlu ditanamkan sejak pendidikan dasar. Hal ini disebabkan pendidikan dasar menjadi dasar bagi jenjang pendidikan selanjutnya. Peserta didik di sekolah dasar masih belum banyak terkontaminasi dengan sifat-sifat yang kurang baik, sehingga pendidikan karakter pada usia sekolah dasar akan memberikan peluang yang lebih besar bagi tertanamnya nilai-nilai karakter positif dalam diri peserta didik. Selain itu, pembelajaran humanis religius juga sangat penting bagi peserta didik di sekolah dasar karena pembelajaran humanis religius mampu menciptakan manusia yang menjunjung tinggi nilai-nilai kemanusiaan.

Pembelajaran humanis religius dalam pendidikan karakter pada peserta didik di jenjang sekolah dasar sangat penting untuk dilaksanakan. Sikap dan tindakan guru dalam pembelajaran sebagai pelaksana pendidikan di kelas adalah hal yang menjadi perhatian utama. Perilaku mengajar yang humanis religius dalam hal ini menitikberatkan pada masalahmasalah kepentingan manusia, nilai-nilai, dan martabat manusia. Dengan demikian, pembelajaran yang humanis religius adalah perilaku mengajar yang memanusiakan peserta didik dengan menghargai martabat dan memperlakukan sesuai dengan karakteristiknya masing-masing. Pembelajaran yang humanis religius merupakan proses belajar mengajar di kelas yang memuat nilai-nilai dasar kemanusiaan untuk mencapai keberhasilan yang benar-benar dijadikan landasan dalam pembentukan moral anak bangsa.

Teori humanis tercipta sebagai suatu spektrum pemikiran modern. Teori humanis telah memberikan hal-hal positif bagi semangat kemanusiaan. Dalam perkembangannya, teori humanis juga berimplikasi negatif bagi pengembangan bidang filsafat dan keagamaan. Keyakinan yang berkembang bahwa hal-hal religius menjadi faktor yang menghambat manusia dari perkembangan dan membawanya kepada konflik. Kaum humanis telah mengklaim bahwa pengingkaran kepercayaan religius akan membuat manusia bahagia. Namun, pengalaman sejarah justru membuktikan sebaliknya.

Enam tahun setelah Manifesto Humanis dipublikasikan, Story (1998, p.143) menjelaskan bahwa Perang Dunia II meletus sebagai sebuah catatan malapetaka yang dibawa ke dunia oleh ideologi fasis yang sekuler. Ideologi humanis juga mendatangkan kekejaman terhadap bangsa-bangsa lain seperti halnya Uni Soviet, Cina, Kamboja, Vietnam, Korea Utara, Kuba, dan berbagai negara Afrika serta 
Amerika Latin. Catatan sejarah inilah yang menjadi bukti bahwa teori humanis sekuler tidak berhasil membawa kedamaian dan kebahagiaan kepada masyarakatnya sendiri ataupun kepada wilayah-wilayah lain di dunia. Keadaan tersebut kemudian memicu lahirnya teori humanis religius sebagai jembatan filosofis antara filsafat dan keagamaan.

Tema pokok dari humanis religius adalah kebebasan manusia yang diperjuangkan bukanlah kebebasan yang absolut atau antithesis. Pada abad pertengahan, hal ini dianggap tidak seimbang antara kepentingan agama dan kepentingan kemanusiaan. Menurut paham humanis religius, keseluruhan jiwa manusia yang memancarkan kebebasan tidak dapat dipisahkan dari dimensi etis individualis manusia dalam ruang (alam) dan waktu (sejarah), sebagai satu kesatuan eksistensial. Humanis religius menjamin kebebasan manusia untuk merancang sendiri kehidupannya di dunia dengan cara yang merdeka. Humanis religius memandang instruksi-instruksi tradisional para pemuka agama, bukan sebagai perintah yang akan membantu berbagai urusan yang mesti dilaksanakan, melainkan sebagai kendala dan rintangan bagi manusia. "Dalam konteks humanis religius, kejahatan dan penghancuran nilai-nilai kemanusiaan justru dianggap menodai ajaran-ajaran agama, dirinya dan para pemeluknya" (Amin, 2011, p.30).

Pengembangan model pembelajaran dalam penelitian ini dilakukan berdasarkan teori humanis religius. Hal ini disebabkan teori humanis religius merupakan konsep dasar yang menjadi cita-cita bangsa Indonesia dalam pengembangan pendidikan. Hal ini dapat diketahui dari rumusan dasar Negara Republik Indonesia yang mengandung pemahaman bahwa praktik pendidikan yang dicita-citakan oleh para pendiri bangsa Indonesia adalah pendidikan yang bercorak humanis religius. Konsep ini ditarik dan diabstraksikan dari bunyi teks Pancasila, terutama sila pertama dan kedua, yaitu Ketuhanan yang Maha Esa serta Kemanusiaan yang Adil dan Beradab. Pancasila menjadi dasar dari Pendidikan Nasional Indonesia yang berdasarkan pada pandangan humanis religius. pada dasarnya, guru sebagai pendidik harus dapat menerapkan paham humanis religius sebagaimana kutipan berikut.

Pendidikan humanis religius dimulai dari guru kepada peserta didik agar praktik pendidikan bersifat mengarahkan, memandirikan, dan memberdayakan peserta didik sebagai makhluk berdimensi horizontal dan vertikal. Humanis religius sangat mementingkan ditonjolkannya nilai-nilai kemanusiaan dalam setiap penghayatan dan pengamalan kehidupan beragama (Adhiatera, 2008, p.173).

"Pandangan humanis religius merupakan suatu perpaduan dua konsep tentang penghargaan kepada kodrati kemanusiaan sekaligus bahwa kodrat itu sebagai ciptaan Tuhan Yang Maha Kuasa" (Mumpuniarti, 2010). Pandangan humanis religius muncul akibat kebebasan manusia yang tidak didikte oleh dogma-dogma, disamping itu sebagai kritik terhadap praktik-praktik kehidupan yang semakin dehumanisasi. Praktik dehumanisasi ditandai dengan penciptaan manusia sebagai mesin, memiliki penguasaan pengetahuan saja untuk kepemilikan material tidak terbatas, yang akhirnya menjadikan manusia mengeksploitasi sumber daya alam terus menerus untuk menindas manusia lainnya maupun untuk membahayakan dirinya sendiri.

Bangsa Indonesia memiliki cara yang unik dalam menjaga dan menumbuhkan nilainilai humanis religius. Sekulerisme radikal tidak menjadi pilihan bagi pengadopsian konsep humanis di Indonesia karena paham tersebut tidak memedulikan agama di ranah publik. Hal ini disebabkan konsep dasar humanis sekuler yang tidak sesuai dengan nilai-nilai budaya Indonesia. Konsep mengenai humanis sekuler dapat dipahami dari kutipan berikut.

Kaum humanis sekuler melihat akal budi manusia sebagai kekuatan yang membimbing dalam hidup, sehingga terdorong untuk membersihkan masyarakat dari kepercayaan-kepercayaan religius yang menurut mereka menghalangi kemajuan manusia (Smith \& Raeper, terjemahan Hadi, 2000, p.133).

Humanis sekuler sangat mempercayai akal budi manusia sehingga terkesan meniadakan agama. Melalui pendidikan yang bercorak humanis religius berlandaskan Pancasila, negara mengakui pluralitas agama sekaligus bertanggung jawab mendidik warga agar menjadi pemeluk agama yang taat.

Menurut teori humanistik, proses belajar harus dimulai dan ditujukan untuk kepentingan memanusiakan manusia itu sendiri. "Sifat teori belajar humanistik lebih abstrak dan lebih mendekati bidang kajian filsafat, teori kepribadian, dan psikoterapi, daripada bi- 
dang kajian psikologi belajar" (Leonard, 2002, p.68). Teori humanistik sangat mementingkan proses belajar untuk mencapai tujuan belajar. Teori belajar humanistik lebih banyak berbicara tentang konsep-konsep pendidikan untuk membentuk manusia yang dicita-citakan, manusia yang humanis, serta tentang proses belajar dalam bentuk yang paling ideal. Dengan ungkapan lain, teori ini lebih tertarik pada proses belajar dalam bentuknya yang paling ideal.

Pembelajaran yang dikembangkan berpijak pada teori belajar humanistik memiliki ciri-ciri humanis, yaitu untuk mencapai kemanusiaan transprimordial berupa kemampuan untuk menghormati martabat, keutuhan dan hak-hak asasi sesama manusia tidak pandang apakah ia termasuk golongan primordial suku, daerah, agama, bangsa sendiri atau lainnya (Comer \& Gloud, 2012, p.18). Diantara nilainilai yang perlu dikembangkan dalam pembelajaran adalah kemampuan untuk menerima pluralisme, yaitu kemampuan untuk hidup berdampingan dan saling menghormati, tanpa mempermasalahkan budaya, adat-istiadat, agama, dan gaya hidup yang berbeda. Hal ini disebabkan Indonesia adalah negara multikultural. Seluruh warga negara Indonesia harus memahami pluralisme dan memahami cara hidup di negara yang multikultural.

Berdasarkan latar belakang permasalahan yang telah diuraikan di atas dapat dipahami pentingnya suatu model pembelajaran humanis religius yang dapat dilaksanakan dalam pendidikan karakter di sekolah dasar. Oleh karena itu, perlu dikembangkan suatu pendekatan pembelajaran dengan pendekatan humanis religius sebagai upaya untuk melaksanakan pendidikan karakter di sekolah dasar. Model pembelajaran humanis religius dalam pendidikan karakter dapat dimaknai sebagai keterpaduan antara aktivitas pengajaran dan pembelajaran dengan penanaman nilai-nilai karakter sebagai landasan pembentuk jati diri bangsa. Model pembelajaran humanis religius didasarkan pada seperangkat asumsi yang berisikan wawasan dan aktifitas berfikir dalam merencanakan pembelajaran dengan memadukan pengetahuan, pengalaman, dan keterampilan sebagai area isi kegiatan belajar mengajar. Model pembelajaran humanis religius dapat mengintegrasikan penanaman nilai-nilai dalam seluruh proses pendidikan. Sesuai dengan prinsip pembelajaran humanis religius, pendidikan karakter tidak hanya mengikutsertakan guru dalam proses pembentukan karakter, akan tetapi juga menempatkan peserta didik sebagai subjek atau individu yang memiliki kemampuan untuk mengorientasikan diri ke tindakan yang benar. Hal inilah yang menjadi landasan pemilihan model pembelajaran humanis religius dalam pendidikan karakter di sekolah dasar.

Dewey (1998, p.80) menyatakan bahwa "pendidikan merupakan metode fundamental dari kemajuan dan pembaruan sosial". Melalui pendidikan, terjadi proses pembentukan kecakapan-kecakapan fundamental secara intelektual dan emosional. Seluruh proses pendidikan dimulai dengan partisipasi individu dalam kesadaran sosial. Dengan demikian, pendidikan juga merupakan proses untuk sampai pada partisipasi dalam kesadaran sosial tersebut.

Pendidikan adalah alat yang dapat digunakan dalam pembangunan moral manusia (Veugelers, 2010, p.1). Visi pedagogis pendidik dapat terinspirasi oleh pandangan dunia yang berbeda, pengalaman budaya, serta ideide politik. Nilai-nilai moral yang diaplikasikan melalui pendidikan kemudian dibangun melalui tingkat sistem pendidikan, sekolah, dan guru sebagai komponen-komponen pendidikan. Dalam pelaksanaanya, pendidikan sendiri membedakan antara nilai-nilai moral, tujuan pedagogis, dan praktik yang dapat dilakukan pada proses pendidikan.

Pada era globalisasi sekarang ini semakin dirasakan betapa pentingnya pengembangan pendidikan, hal ini disebabkan karena banyaknya teknologi yang bermunculan atau pesatnya peradaban yang akan menuntut kesiapan sumber daya manusia yang lebih matang dalam segala hal. Bidang pendidikan merupakan salah satu andalan yang dibutuhkan untuk mempersiapkan sumber daya manusia yang dibutuhkan untuk memenuhi tuntutan zaman. Persiapan sumber daya manusia dalam bidang pendidikan harus dilakukan mulai dari pendidikan dasar, menengah, hingga pendidikan tinggi.

Berdasarkan fungsi dan tujuan pendidikan nasional, jelas bahwa pendidikan di setiap jenjang, termasuk sekolah dasar harus diselenggarakan secara sistematis guna mencapai tujuan tersebut. Hal tersebut tentunya berkaitan dengan pembentukan karakter peserta didik sehingga mampu bersaing, ber- 
etika, bermoral, memiliki sopan santun, dan mampu berinteraksi dengan masyarakat. Karakter dapat dipahami sebagai struktur antropologis manusia sebagai tempat manusia menghayati kebebasan dan mengatasi keterbatasan dirinya (Albertus, 2007, p.3). Struktur antropologis ini melihat bahwa karakter bukan sekedar hasil dari sebuah tindakan, melainkan secara simultan merupakan hasil dan proses. Dinamika ini menjadi semacam dialektika dalam diri manusia untuk menghayati kebebasannya dan mengatasi keterbatasannya. Karakter merupakan kondisi dinamis struktur antropologis individu yang tidak mau sekedar berhenti atas determinasi kodratinya, melainkan juga sebuah usaha hidup untuk menjadi semakin integral mengatasi determinasi alam dalam dirinya demi proses penyempurnaan diri secara terus menerus.

Berdasarkan pada latar belakang masalah, identifikasi masalah, pembatasan masalah, dan fokus penelitian di atas maka penelitian ini mengacu pada beberapa rumusan masalah, yaitu: (1) bagaimanakah pengembangan pendekatan pembelajaran humanis yang dapat mewujudkan tujuan pendidikan karakter pada jenjang sekolah dasar?, (2) bagaimanakah penerapan model pembelajaran humanis religius dalam pendidikan karakter pada sekolah dasar?, (3) bagaimanakah keefektifan model pembelajaran humanis religius dalam menanamkan nilai-nilai karakter dalam diri peserta didik di sekolah dasar?, dan (4) bagaimanakah tanggapan peserta didik terhadap model pembelajaran humanis religius dalam pendidikan karakter di sekolah dasar? Guna menjawab rumusan masalah tersebut maka penelitian ini dilakukan dengan tujuan: (1) untuk mengetahui pengembangan pendekatan pembelajaran humanis yang dapat mewujudkan tujuan pendidikan karakter pada jenjang sekolah dasar, (2) untuk mengetahui penerapan model pembelajaran humanis religius dalam pendidikan karakter pada sekolah dasar, (3) untuk menganalisis keefektifan model pembelajaran humanis religius dalam menanamkan nilai-nilai karakter dalam diri peserta didik di sekolah dasar, dan (4) untuk menganalisis tanggapan peserta didik terhadap model pembelajaran humanis religius dalam pendidikan karakter di sekolah dasar.

Secara teoritis, penelitian ini bermanfaat untuk mengembangkan teori tentang model pembelajaran humanis religius dalam pendidikan karakter di jenjang sekolah dasar. Secara praktis penelitian ini diharapkan dapat: (1) menanamkan nilai-nilai karakter dalam diri peserta didik melalui pembelajaran humanis religius di sekolah dasar, (2) dapat menemukan pendekatan pembelajaran yang efektif dalam pendidikan karakter sehingga dapat dijadikan salah satu solusi atas problem pendidikan karakter yang dihadapi sekolah dasar, dan (3) dengan menemukan pengembangan pola pendidikan karakter melalui model pembelajaran humanis religius, maka dapat digunakan juga sebagai pola pendidikan karakter untuk sekolah lain yang memiliki kesamaan masalah dengan lokasi penelitian.

\section{METODE PENELITIAN}

\section{Jenis Penelitian}

Penelitian ini menggunakan jenis penelitian dan pengembangan atau Research \& Development khususnya dalam bidang pendidikan. Penelitian dan pengembangan pendidikan merupakan suatu pendekatan penelitian yang digunakan untuk merencanakan, merumuskan, memvalidasi, dan merevisi suatu produk pendidikan sehingga memenuhi kriteria validitas, praktikalitas, dan efektifitas. Implementasi dari penelitian Research \& Development dalam penelitian ini dilakukan dengan tujuan untuk menghasilkan produk berupa model pembelajaran humanis religius untuk pendidikan karakter pada sekolah dasar. Prosedur Pengembangan

Khususnya Langkah-langkah pengembangan yang dilakukan pada penelitian ini mengacu pada urutan yang dikemukakan oleh Borg \& Gall (1989, pp.784-785). Prosedur yang dilaksanakan dalam penelitian ini terkait dengan langkah-langkah penelitian pengembangan yang disajikan Borg \& Gall. Untuk lebih jelasnya mengenai tahap-tahap pada prosedur penelitian adalah sebagai berikut: (1) studi pendahuluan dan pengumpulan informasi; (2) perencanaan; (3) pengembangan produk awal; (4) uji lapangan awal; (5) revisi produk; (6) uji lapangan utama; (7) revisi produk operasional; (8) uji lapangan operasional; (9) revisi produk akhir; (10) diseminasi dan Implementasi

\section{Subjek Penelitian}

Subjek coba pada penelitian ini terdiri dari 3 kelompok subjek. Masing-masing ke- 
lompok subjek penelitian diambil dari kelas $\mathrm{V}$ SD Negeri di Kecamatan Banguntapan Kabupaten Bantul, yang meliputi peserta didik, guru kelas, dan kepala sekolah selaku pimpinan. Sebagaimana telah dijelaskan pada Bab I sebelumnya bahwa pembelajaran humanis religius dalam pendidikan karakter di sekolah dasar diterapkan pada kelas V SD karena peserta didik pada kelas $\mathrm{V}$ berada pada rentang usia 11-12 tahun, yang mulai memasuki masa praremaja. Fase ini merupakan fase negatif, dimana anak seringkali menunjukkan tingkah laku yang cenderung negatif (Hurlock dalam Sobur, 2003, p.134). Oleh karena itu, sangat perlu membekali siswa dengan nilainilai karakter positif melalui penerapan model pembelajaran humanis religius.

Subjek coba penelitian ini adalah sebanyak 3 Sekolah Dasar (SD) dari 23 SD Negeri di Kecamatan Banguntapan Kabupaten Bantul. SD Negeri di Kecamatan Banguntapan Kabupaten Bantul tersebar di berbagai lokasi, yaitu di tengah kota, di pinggiran kota, dan di antaranya. Alasan pemilihan SD Negeri sebagai subjek coba disebabkan SD Negeri dapat dijadikan tolok ukur dalam proses pendidikan karakter. Di samping itu, guru kelas pada SD negeri adalah Pegawai Negeri Sipil (PNS) yang memiliki sertifikat pendidik atau sudah tersertifikasi. Sementara itu, guru-guru pada SD swasta kebanyakan belum PNS atau belum memiliki sertifikat pendidik. Oleh karena itu, SD swasta yang berada di wilayah Kecamatan Banguntapan dinilai belum dapat dijadikan pedoman atas keberhasilan pembelajaran humanis religius dalam pendidikan karakter di jenjang sekolah dasar.

\section{Data, Intrumen, dan Teknik Pengumpulan Data}

Data yang diperoleh dalam penelitian ini merupakan data kuantitatif serta data kualitatif. Data tersebut memberi gambaran tentang efektivitas model pembelajaran, proses pembelajaran yang telah dilaksanakan dan output yang dicapai dari proses pembelajaran humanis religius yang telah dilaksanakan.

Pengumpulan data dilakukan melalui wawancara dan penyebaran angket. Wawancara dilakukan pada saat studi pendahuluan. Instrumen penelitian terdiri dari instrumen pedomen wawancara dan angket. Angket yang digunakan dalam penelitian ini adalah berikut: (1) perilaku mengajar yang humanis dari guru kelas; (2) kepribadian guru kelas; (3) fasilitas yang mendukung pembelajaran; (4) media pembelajaran yang digunakan; (5) respon peserta didik terhadap pembelajaran; (6) proses pembelajaran; (7) output pembelajaran; (8) validasi model pembelajaran humanis religius; (9) efektivitas model pembelajaran; (10) kepraktisan model pembelajaran; (11) keterlaksanaan Model pembelajaran.

\section{Teknik Analisis Data}

Analisis data dalam penelitian ini dilakukan melalui analisis kualitatif dan analisis kuantitatif. Analisis data secara deskriptif kualitatif dilakukan terhadap data hasil studi pendahuluan. Pada penelitian ini, analisis data secara kualitatif dilakukan dengan memberikan narasi yang logis sesuai dengan tujuan penelitian. Adapun yang dimaksud dengan data kualitatif dalam penelitian ini hanya sebatas data mengenai gambaran pendidikan karakter di lokasi penelitian. Hasil studi pendahuluan tersebut antara lain data mengenai pembelajaran untuk pendidikan karakter yang telah dilakukan di sekolah dasar.

Analisis kuantitatif yang dilakukan dalam penelitian ini meliputi analisis keterlaksanaan, keefektivan, kepraktisan, dan kevalidan model. Analisis data keterlaksanaan model dilakukan melalui analisis deskriptif dan perhitungan tingkat percentages of agreements antara penilai. Analisis data keefektifan dan kepraktisan model dilakukan melalui analisis deksriptif. Analisis data kevalidan model dilakukan dengan analisis deskriptif dan pengukuran tingkat kesepahaman antarpenilai melalui Coefficient Cohen's Kappa.

\section{HASIL DAN PEMBAHASAN}

\section{Hasil Pengembangan}

Pengembangan model pembelajaran humanis religius dalam pendidikan karakter di sekolah dasar diawali dengan wawancara pendahuluan dan observasi lapangan. Wawancara dan observasi dilakukan secara bersamaan di lapangan penelitian. Hal ini dilakukan bersamaan dengan penyusunan proposal penelitian. Wawancara dilakukan dengan praktisi dan guru pada SD Jomblangan, SD Baturetno, dan SD Jaranan yang terdapat di Kecamatan Banguntapan Kabupaten Bantul. Observasi dilakukan terhadap kegiatan pembelajaran dan peserta didik pada ketiga sekolah dasar tersebut. 
Kegiatan pokok pada tahap pra-pengem-bangan meliputi beberapa fase, yaitu investigasi awal, desain, dan realisasi/konstruksi produk. Tahap investigasi awal diawali dengan pengumpulan informasi mengenai pendidikan karakter yang telah dilaksanakan, metode pembelajaran yang diterapkan di sekolah dasar, serta nilai-nilai karakter yang dapat dikembangkan di sekolah dasar. Investigasi awal dilaksanakan untuk mengetahui kebutuhan praktisi pendidikan terhadap model pembelajaran dan permasalahan dalam pendidikan karakter di sekolah dasar.

Berdasarkan hasil diskusi dengan praktisi pendidikan, diperoleh beberapa nilai karakter yang dapat dikembangkan di tingkat sekolah dasar. Nilai-nilai karakter tersebut terdiri dari nilai: (1) religius, (2) jujur, (3) toleransi, (4) disiplin, dan (5) kerja keras. Nilainilai karakter inilah yang kemudian dijadikan fokus dalam pengembangan pembelajaran humanis dalam pendidikan karakter di sekolah dasar. Nilai-nilai karakter tersebut harus diterapkan dalam setiap mata pelajaran di kelas, bukan diintegrasikan dengan mata pelajaran tertentu.

\section{Hasil Ujicoba Produk}

1. Tahap Ujicoba Terbatas

a. Kualitas Model pembelajaran Humanis Religius yang Dapat Mewujudkan Tujuan Pendidikan Karakter di Sekolah Dasar

1) Keterlaksanaan Model pembelajaran $\mathrm{Hu}$ manis religius dalam Pendidikan Karakter di Sekolah Dasar

Keterlaksanaan model pembelajaran humanis religius dalam pendidikan karakter di sekolah dasar dapat dilihat dari pelaksanaan ujicoba produk. Hasil penelitian menunjukkan bahwa keterlaksanaan model pembelajaran humanis religius dalam pendidikan karakter di sekolah dasar dapat dikatakan baik. Perilaku mengajar guru kelas mayoritas tergolong dalam kategori baik. Guru kelas memiliki pilihan dan kendali diri yang sangat baik, serta mampu mengganggap bahwa peserta didik adalah manusia seutuhnya dengan sangat baik. Perhatian guru kelas terhadap peserta didik tergolong baik. Begitu pula halnya dengan kemampuan guru mengevaluasi diri dan kemampuan bertindak sebagai fasilitator.

Dari segi kepribadian dapat dilihat bahwa guru kelas memiliki kepribadian yang sangat baik. Respon peserta didik terhadap model pembelajaran humanis religius dalam pendidikan karakter di sekolah dasar yang telah diterapkan juga tergolong sangat baik. Seluruh aspek dari fasilitas pembelajaran sudah baik dan media pembelajaran yang tersedia untuk digunakan dalam pembelajaran tergolong baik. Kondisi ini memperlihatkan bahwa keterlaksanaan model pembelajaran humanis religius dalam pendidikan karakter di sekolah dasar pada dasarnya sudah tergolong baik.

Keterlaksanaan produk pada dasarnya adalah terlaksananya seluruh aktifitas pembelajaran sesuai dengan sintaks atau tahapantahapan pembelajaran yang telah dirancang pada buku pedoman pembelajaran. Persentasi keterlaksanaan produk diamati oleh pengamat yang membantu peneliti mengamati seluruh aktivitas selama proses pembelajaran berlangsung. Tingkat keterlaksanaan model pembelajaran humanis religius diukur melalui pengamatan oleh dua orang pengamat terhadap seorang guru yang sedang menerapkan produk selama pembelajaran berlangsung. Pengamatan dilakukan sebanyak 1 kali dalam 1 periode penilaian ( 2 minggu). Pada instrumen pengamatan terhadap tingkat keterlaksanaan ini terdapat 15 item pernyataan yang harus dijawab dengan "Ya" untuk item yang terlaksana dan dengan "Tidak" jika tidak terlaksana. Persentase keterlaksanaan di atas dapat juga digambarkan sebagaimana berikut.

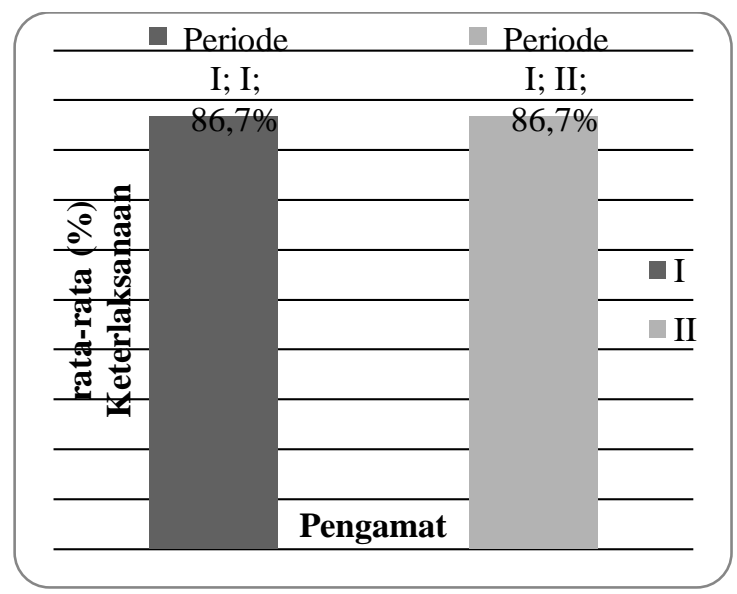

Gambar 1. Diagram Batang Hasil Analisis Data Keterlaksanaan Ujicoba

Pada gambar di atas, tampak bahwa tidak ada perbedaan hasil pengamatan antara pengamat 2 dan pengamat 2 terhadap tingkat keterlaksanaan model pembelajaran humanis religius pada ujicoba. Masing-masing peng- 
amat menunjukkan persentase sebesar $86,7 \%$. Untuk menjamin reliabilitas hasil pengamatan keterlaksanaan model pembelajaran humanis religius dalam pendidikan karakter di sekolah dasar, dilakukan analisis reliabilitas antar pengamat dengan menggunakan formula Persentase Kesepakatan.

Hasil pengamatan dari 2 orang pengamat yang merupakan teman sejawat guru kelas menunjukkan nilai persentase kesepakatan sebesar $66,7 \%$ yang termasuk dalam kategori baik (good agreement). Hasil analisis tersebut menunjukkan bahwa kedua pengamat memiliki persepsi pemahaman yang hampir sama bahwa keterlaksanaan sintaks model pembelajaran humanis religius dalam pendidikan karakter di sekolah dasar tergolong baik sesuai yang diharapkan dengan tingkat keajegan yang tinggi.

Berdasarkan hasil pengamatan juga terlihat bahwa guru sudah menjadi fasilitator dalam pembelajaran namun demikian, guru masih terlihat kesulitan dalam memberikan motivasi kepada peserta didik untuk belajar dan mencari sumber belajar sendiri. Hasil pengamatan terhadap aktivitas guru menunjukkan bahwa dalam pembelajaran pada ujicoba terbatas guru telah melakukan aktivitas mengajar dengan baik dan sesuai dengan buku pedoman pembelajaran humanis religius.

2) Keefektifan Model pembelajaran Humanis religius dalam Pendidikan Karakter di Sekolah Dasar

Keefektifan model pembelajaran diukur melalui lembar penilaian tersendiri. Lembar keefektifan dinilai oleh guru kelas yang menggunakan model pembelajaran. Hasil penilaian dari beberapa aspek yang dinilai dalam lembar keefektifan model pembelajaran dapat dilihat pada Gambar 2.

Gambar 2 memperlihatkan bahwa model pembelajaran humanis religius dalam pendidikan karakter di sekolah dasar dinilai sangat efektif oleh guru. Rata-rata hasil penilaian keefektifan produk menunjukkan nilai sebesar 4,7 yang berada dalam kategori sangat efektif. Seluruh aspek keefektifan memiliki nilai yang tergolong sangat efektif. Aspek yang memiliki tingkat efektifitas paling tinggi adalah objektivitas produk, yaitu sebesar 5,0. Artinya model pembelajaran humanis religius dalam pendidikan karakter di sekolah dasar sangat efektif digunakan untuk mengembangkan karakter peserta didik.

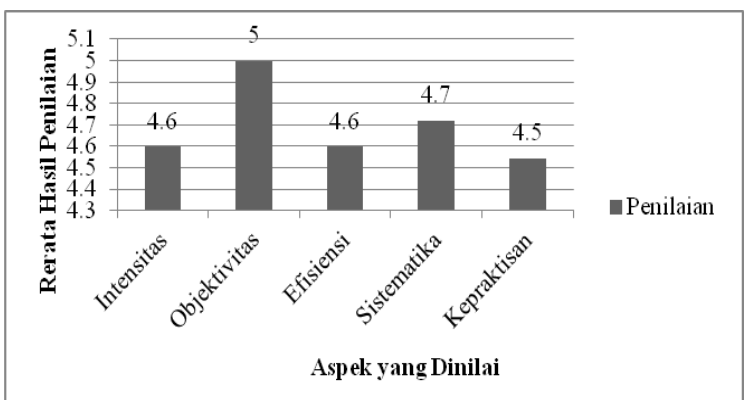

Gambar 2. Diagram Batang Hasil Analisis Data Keefektifan

Berdasarkan gambar di atas terlihat hasil penilaian guru pada ujicoba terbatas menunjukkan bahwa penerapan model pembelajaran humanis religius dalam pendidikan karakter di sekolah dasar sangat objektif. Selain itu, model pembelajaran juga memiliki sistematika yang baik. Proses pembelajaran yang berjalan selama 2 minggu juga telah menunjukkan bahwa pembelajaran berlangsung dengan baik. Namun demikian, produk belum dapat dikatakan efektif dengan baik tanpa diiringi oleh keberhasilan output pembelajaran.

Nilai karakter peserta didik sebelum dan sesudah pelaksanaan pembelajaran humanis religius dalam pendidikan karakter di sekolah dasar. Berdasarkan tabel tersebut dapat dilihat bahwa nilai karakter peserta didik mengalami peningkatan. Karakter yang yang mulai berkembang adalah religius, jujur, toleransi, dan disiplin, sedangkan nilai kerja keras masih termasuk dalam kategori mulai terlihat. Secara kuantitatif, nilai karakter tertinggi adalah nilai religius, yaitu sebesar 3,8 . Kejujuran, toleransi, dan disiplin menunjukkan nilai yang sama, yaitu 3,00. Kerja keras merupakan nilai karakter yang paling kecil, yaitu sebesar 2,7.

Apabila dilihat dari fakta yang terjadi di lapangan, dapat dipahami bahwa ada perubahan pada penerapan nilai-nilai karakter dalam diri peserta didik, terkait nilai karakter religius, jujur, toleransi, disiplin, dan kerja keras. Hal ini dapat dilihat dari indikator perilaku peserta didik. pada awal pembelajaran, sudah ada sebagian kecil peserta didik yang menunjukkan nilai karakter positif dalam perilakunya sehari-hari. Namun demikian, masih banyak peserta didik yang tidak menunjukkan nilai karakter positif. Setelah pelaksanaan pembelajaran humanis religius dalam pendidikan karakter di sekolah dasar diterapkan 
selama 2 minggu, terjadi perubahan pada perilaku peserta didik. Mayoritas peserta didik sudah menerapkan nilai karakter positif yang tertanam dalam dirinya.

Selanjutnya, dapat diketahui hasil uji paired t test guna mengetahui perbedaan tertanamnya nilai-nilai karakter dalam diri peserta didik sebelum dan sesudah pelaksanaan pendidikan karakter. Pengujian antara hasil nilai karakter awal dan nilai karakter akhir yang tertanam dalam diri peserta didik, nilai $t_{\text {hitung }}$ adalah sebesar 9,721 dengan nilai $p$ 0,000 . Nilai $t_{\text {tabel }}$ untuk $\alpha=5 \%$ adalah sebesar 1,721. Hasil pengujian ini menunjukkan bahwa nilai $t_{\text {hitung }}>t_{\text {tabel }}$, yaitu $9,721>1,721$ dan nilai $\mathrm{p}<0,05$. Kondisi ini menunjukkan bahwa ada perbedaan yang signifikan antara nilai karakter awal dengan nilai karakter akhir. Hasil ini menunjukkan bahwa ada pengaruh model pembelajaran humanis religius dalam pendidikan karakter di sekolah dasar terhadap penanaman karakter dalam diri peserta didik.

3) Kepraktisan Model pembelajaran Humanis religius dalam Pendidikan Karakter di Sekolah Dasar

Model pembelajaran humanis religius dalam pendidikan karakter di sekolah dasar termasuk dalam kategori sangat praktis. Secara keseluruhan dapat diketahui bahwa ratarata penilaian terhadap keseluruhan aspek bernilai sebesar 4,4 dengan kategori sangat praktis. Apabila dilihat dari masing-masing aspek maka dapat diketahui bahwa aspek yang paling praktis adalah sistem sosial produk dengan nilai rata-rata sebesar 4,6 dengan kategori sangat praktis.

4) Kevalidan Model pembelajaran Humanis religius dalam Pendidikan Karakter di Sekolah Dasar

Tingkat kesepakatan (reliabilitas) antar penilai tersebut dapat dijelaskan dengan menghitung koefisien reliabilitas antarpenilai menggunakan koefisien Cohen's Kappa (к). Berikut hasil analisis statistik Cohen's Kappa

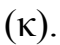

Tabel 1. Hasil Penilaian Setelah Ujicoba

\begin{tabular}{lll}
\hline \multicolumn{1}{c}{ Perangkat } & $\begin{array}{c}\text { Koefisien } \\
\text { Cohen's } \\
\text { Kappa }(\boldsymbol{\kappa})\end{array}$ & \multicolumn{1}{c}{$\begin{array}{c}\text { Kategori } \\
\text { Kesepakatan }\end{array}$} \\
\hline Buku Panduan Produk & 0,851 & Sangat baik \\
Instrumen Penilaian & 0,831 & Sangat baik \\
\hline
\end{tabular}

Keterangan Penilaian:

$$
\begin{array}{ll}
\kappa<0.40 & \text { : Kurang } \\
0.40<\kappa<0.75 & : \text { Baik } \\
\kappa>0.75 & \text { : Sangat baik }
\end{array}
$$

Tabel di atas memperlihatkan bahwa model pembelajaran humanis religius dalam pendidikan karakter dan perangkat penilaiannya yang dikembangkan memiliki kategori kevalidan yang tergolong sangat baik dan reliabel setelah ujicoba terbatas.

b. Tanggapan Peserta Didik terhadap Model pembelajaran Humanis religius Dalam Pendidikan Karakter di Sekolah Dasar

Respon peserta didik terhadap model pembelajaran humanis religius yang dilaksanakan di jenjang sekolah dasar dapat menunjukkan keberhasilan pelaksanaan pembelajaran. Respon peserta didik dinilai oleh 2 orang pengamat dan guru kelas yang melaksanakan pembelajaran dengan hasil sebagai berikut.

Tabel 2. Hasil Penilaian Respon peserta didik pada Ujicoba

\begin{tabular}{lcccccc}
\hline Pengukuran & $\begin{array}{c}\text { Teman } \\
\text { Sejawat 1 }\end{array}$ & $\begin{array}{c}\text { Teman } \\
\text { Sejawat 2 } 2\end{array}$ & $\begin{array}{c}\text { Guru } \\
\text { Kelas }\end{array}$ & Rerata & Kategori \\
\hline $\begin{array}{l}\text { Respon peserta } \\
\text { didik terhadap }\end{array}$ & 4,4 & 4,4 & 4,4 & 4,4 & $\begin{array}{c}\text { Sangat } \\
\text { Baik }\end{array}$ \\
$\begin{array}{l}\text { Model } \\
\text { pembelajaran }\end{array}$ & & & & & \\
\hline
\end{tabular}

Tabel di atas menunjukkan bahwa respon peserta didik terhadap model pembelajaran humanis religius dalam pendidikan karakter di sekolah dasar yang telah diterapkan tergolong sangat baik. Kondisi ini model pembelajaran humanis religius dalam pendidikan karakter di sekolah memperoleh tanggapan yang sangat baik dari peserta didik. Artinya, peserta didik dapat menerima model pembelajaran humanis religius dalam pendidikan karakter di sekolah dasar.

Pengamatan terhadap perilaku peserta didik selama proses pembelajaran berlangsung menunjukkan hasil yang cukup memuaskan. Ada peningkatan yang signifikan dalam keaktifan peserta didik mengikuti pembelajaran. Pada awal pelaksanaan pembelajaran humanis religius, peserta didik masih pasif dan menunggu guru untuk menyampaikan materi saja. Namun setelah berjalan selama 1 minggu, peserta didik mulai aktif dan bersemangat mengkuti pembelajaran. peserta didik juga aktif bertanya dan menjawab pertanyaan guru 
atau mengajak temannya berdiskusi. peserta didik mulai percaya diri mengungkapkan pendapat dan konsentrasi dalam mengikuti pelajaran. Berdasarkan hasil analisis data hasil ujicoba dapat dikatakan bahwa draft produk telah terlaksana dengan baik dan memenuhi kategori valid, efektif, dan praktis. Namun demikian, masih perlu dilakukan revisi penyempurnaan produk guna mengatasi hambatan dan keluhan guru dalam pelaksanaan pembelajaran humanis religius dalam pendidikan karakter di sekolah dasar. Revisi juga dilaksanakan untuk menyempurnakan model pembelajaran.

\section{Tahap Implementasi}

a. Kualitas Model pembelajaran Humanis religius yang Dapat Mewujudkan Tujuan Pendidikan Karakter di Sekolah Dasar

1) Keterlaksanaan Model pembelajaran $\mathrm{Hu}$ manis religius dalam Pendidikan Karakter di Sekolah Dasar

Keterlaksanaan model pembelajaran humanis religius dalam pendidikan karakter yang diimplementasikan di sekolah dasar dapat dikatakan sangat baik. Kedua sekolah dasar yang dijadikan sebagai lokasi penelitian memiliki rata-rata nilai untuk perilaku mengajar guru kelas yang tergolong dalam kategori sangat baik pada seluruh aspek. Guru kelas memiliki pilihan dan kendali diri yang sangat sangat baik, serta mampu mengganggap bahwa peserta didik adalah manusia seutuhnya dengan sangat baik. Perhatian guru kelas terhadap peserta didik tergolong sangat baik. Begitu pula halnya dengan kemampuan guru mengevaluasi diri dan kemampuan bertindak sebagai fasilitator.

Kepribadian guru kelas juga sudah tergolong dalam kategori sangat baik. Aspek dari fasilitas pembelajaran sudah tergolong baik bahkan sangat baik dan kondisi media pembelajaran yang tersedia untuk digunakan $\mathrm{d}$ alam pembelajaran tergolong sangat baik. Hal ini memperlihatkan bahwa keterlaksanaan model pembelajaran humanis religius dalam pendidikan karakter di sekolah dasar pada dasarnya sudah tergolong baik.

Sebagaimana telah dijelaskan pada uji coba sebelumnya bahwa analisis kepraktisan model pembelajaran humanis religius dalam pendidikan karakter di sekolah dasar adalah tingkat keterlaksanaan seluruh tahapan pembelajaran (sintaks). Kegiatan pengamatan pada saat implementasi dilakukan sebanyak 2 kali. Kegiatan pengamatan dilaksanakan pada akhir periode 2 minggu pertama pembelajaran dan pada akhir periode 2 minggu berikutnya. Hasil analisis keterlaksanaan model pembelajaran humanis religius dalam pendidikan karakter di sekolah dasar dapat dilihat pada Gambar3.

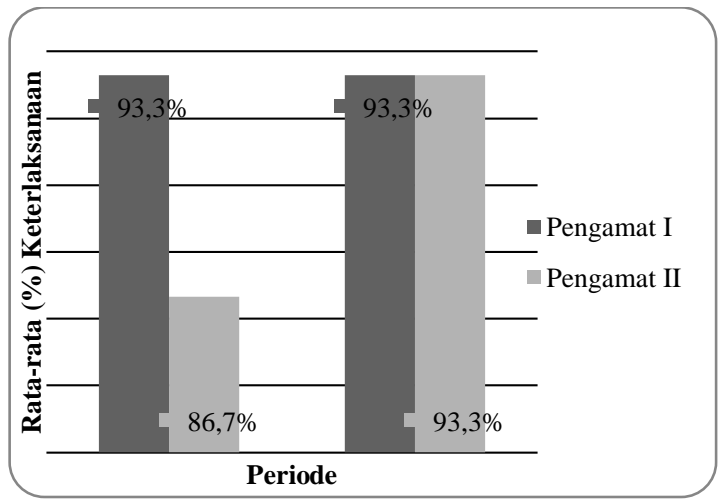

Gambar 3. Diagram Batang Hasil Analisis Data Keterlaksanaan Implementasi

Pada gambar di atas, tampak bahwa ada perbedaan hasil pengamatan antara pengamat 1 dan pengamat 2 terhadap tingkat keterlaksanaan model pembelajaran humanis religius pada saat implementasi tahap awal atau periode I. Pengamat 1 menilai persentase keterlaksanaan sebesar 93,3\%, sedangkan pengamat 2 sebesar $86,7 \%$. Berbeda dengan penilaian pada periode I, pada periode II tidak ada perbedaan hasil pengamatan. Masing-masing pengamat menunjukkan persentase sebesar 93,9\% pada akhir pelaksanaan implementasi. Untuk menjamin reliabilitas hasil pengamatan keterlaksanaan model pembelajaran humanis religius dalam pendidikan karakter di sekolah dasar, dilakukan analisis reliabilitas antar pengamat dengan menggunakan formula Persentase Kesepakatan.

Hasil pengamatan dari 2 orang pengamat menunjukkan nilai PA sebesar $80,0 \%$ pada periode pengamatan I dan sebesar $86,7 \%$ pada periode pengamatan II. Kedua nilai ini termasuk dalam kategori baik (good agreement). Hasil analisis tersebut menunjukkan bahwa kedua pengamat memiliki persepsi pemahaman yang hampir sama, bahwa keterlaksanaan sintaks model pembelajaran humanis religius dalam pendidikan karakter di sekolah dasar tergolong baik sesuai yang diharapkan dengan tingkat keajegan yang tinggi. 
2) Keefektifan Model pembelajaran $\mathrm{Hu}$ manis religius dalam Pendidikan Karakter di Sekolah Dasar

Dalam implementasi model pembelajaran, keefektifan produk juga dinilai oleh guru yang menggunakan model pembelajaran. Keefektifan model pembelajaran juga diukur melalui lembar penilaian tersendiri. Lembar keefektifan dinilai oleh guru kelas yang menggunakan model pembelajaran. Hasil penilaian dari beberapa aspek yang dinilai dalam lembar keefektifan model pembelajaran dapat dilihat pada gambar berikut.

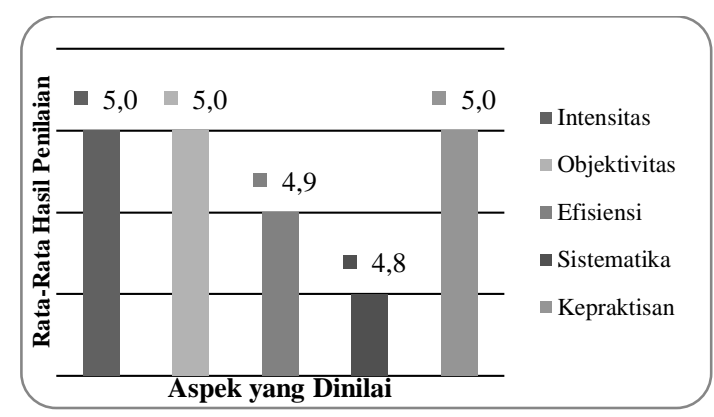

Gambar 4. Diagram Batang Hasil Analisis Data Keefektifan Setelah Implementasi

Berdasarkan gambar di atas terlihat hasil penilaian guru pada implementasi menunjukkan bahwa penerapan model pembelajaran humanis religius dalam pendidikan karakter di sekolah dasar sudah memenuhi kategori yang paling tinggi dalam hal intensitas, objektivitas, dan kepraktisan. Ketiga aspek tersebut memiliki nilai tertinggi. Aspek yang memiliki nilai terendah adalah sistematika. Namun demikian, seluruh aspek tersebut sudah memiliki nilai yang tergolong dalam kategori sangat efektif.

Model pembelajaran humanis religius dalam pendidikan karakter di sekolah dasar dinilai sangat efektif oleh guru di kedua sekolah dasar. Rata-rata hasil penilaian keefektifan produk menunjukkan nilai sebesar 4,9 yang berada dalam kategori sangat efektif. Seluruh aspek keefektifan memiliki nilai ratarata yang tergolong sangat efektif. Aspek yang memiliki tingkat efektifitas paling tinggi adalah intensitas, objektivitas, dan praktis, yaitu sebesar 5,0. Proses pembelajaran yang berjalan selama 1 bulan juga telah menunjukkan bahwa pembelajaran berlangsung dengan sangat baik pada periode I dan periode II.

Hasil penelitian menunjukkan bahwa terjadi peningkatan nilai karakter dalam diri peserta didik pada saat penilaian awal, periode 1 , dan periode 2 . Nilai karakter yang mengalami peningkatan pada periode II. Pada periode I, SD Jomblangan memiliki 3 nilai membudaya dan 2 nilai mulai berkembang. Pada periode II, meningkat menjadi 5 nilai membudaya. Sedikit berbeda, pada periode I SD Jaranan sudah memiliki 5 nilai membudaya. Pada periode II, SD Jaranan juga memiliki 5 nilai membudaya. Selanjutnya dapat diketahui hasil uji paired $t$ test guna mengetahui perbedaan tertanamnya nilai-nilai karakter dalam diri peserta didik sebelum dan sesudah pelaksanaan pendidikan karakter periode I dan periode II.

Pada pengujian implementasi di SD Jomblangan, hasil nilai karakter awal dan nilai karakter akhir periode I yang tertanam dalam diri peserta didik menunjukkan nilai $t_{\text {hitung }}$ adalah sebesar 12,693 dengan nilai $\mathrm{p} 0,000$. Nilai $t_{\text {tabel }}$ untuk $\alpha=5 \%$ adalah sebesar 1,721 . Hasil pengujian ini menunjukkan bahwa nilai $\mathrm{t}_{\text {hitung }}>\mathrm{t}_{\text {tabel }}$, yaitu 12,693>1,721 dan nilai $\mathrm{p}<$ 0,05 . Kondisi ini menunjukkan bahwa ada perbedaan yang signifikan antara nilai karakter awal dengan nilai karakter akhir periode I. Begitu pula halnya dengan perbedaan nilai karakter periode I dengan akhir periode II. Nilai $t_{\text {hitung }}$ adalah sebesar 4,183 dengan nilai $p$ 0,000 . Nilai $t_{\text {hitung }}$ pengujian perbedaan antara nilai karakter akhir periode I dengan akhir periode II adalah sebesar 4,183, sedangkan nilai $t_{\text {tabel }}$ untuk $\alpha=5 \%$ adalah sebesar 1,721 . Hasil pengujian ini menunjukkan bahwa nilai $t_{\text {hitung }}>t_{\text {tabel }}$, yaitu 4,183>1,721 dan nilai $p<$ 0,05 . Kondisi ini menunjukkan bahwa ada perbedaan yang signifikan antara nilai karakter akhir periode I dengan nilai karakter akhir periode II. Hasil ini menunjukkan bahwa ada pengaruh model pembelajaran humanis religius dalam pendidikan karakter di sekolah dasar terhadap penanaman karakter dalam diri peserta didik di SD Jomblangan.

Hasil pengujian data yang diperoleh dari implementasi di SD Jaranan tidak jauh berbeda. Hasil nilai karakter awal dan nilai karakter akhir periode I yang tertanam dalam diri peserta didik menunjukkan nilai $t_{\text {hitung }}$ adalah sebesar 14,223 dengan nilai $\mathrm{p} 0,000$. Nilai $t_{\text {tabel }}$ untuk $\alpha=5 \%$ adalah sebesar 1,721 . Hasil pengujian ini menunjukkan bahwa nilai $\mathrm{t}_{\text {hasil }}>\mathrm{t}_{\text {tabel }}$, yaitu 14,223 > 1,721 dan nilai $\mathrm{p}<$ 0,05 . Kondisi ini menunjukkan bahwa ada perbedaan yang signifikan antara nilai karak- 
ter awal dengan nilai karakter akhir periode I. Begitu pula halnya dengan perbedaan nilai karakter periode I dengan akhir periode II. Nilai $t_{\text {hitung }}$ adalah sebesar 3,813 dengan nilai $p$ 0,001 . Nilai $t_{\text {hitung }}$ pengujian perbedaan antara nilai karakter akhir periode I dengan akhir periode II adalah sebesar 8,837. Nilai $\mathrm{t}_{\text {tabel }}$ untuk $\alpha=5 \%$ adalah sebesar 1,721. Hasil pengujian ini menunjukkan bahwa nilai $t_{\text {hitung }}$ $>\mathrm{t}_{\text {tabel }}$, yaitu 3,813 $>1,721$ dan nilai $\mathrm{p}<0,05$. Kondisi ini menunjukkan bahwa ada perbedaan yang signifikan antara nilai karakter akhir periode I dengan nilai karakter akhir periode II di SD Jaranan. Hasil ini menunjukkan bahwa ada pengaruh model pembelajaran humanis religius dalam pendidikan karakter di sekolah dasar terhadap penanaman karakter dalam diri peserta didik di SD Jaranan. Melalui hasil yang diperoleh pada pengujian ini dapat dikatakan bahwa model pembelajaran humanis religius dalam pendidikan karakter di sekolah dasar efektif untuk menanamkan karakter dalam diri peserta didik di SD Jomblangan.

3) Kepraktisan Model pembelajaran $\mathrm{Hu}$ manis religius dalam Pendidikan Karakter di Sekolah Dasar

Setelah diketahui bahwa implementasi model pembelajaran humanis religius dalam pendidikan karakter di sekolah dasar berlangsung dengan sangat efektif, maka perlu dinilai kepraktisan model pembelajaran. Kepraktisan model pembelajaran humanis religius dalam pendidikan karakter di sekolah dasar juga dinilai oleh guru pada kedua sekolah dasar yang menjadi pengguna model pembelajaran. Model pembelajaran humanis religius dalam pendidikan karakter di sekolah dasar termasuk dalam kategori sangat praktis. Secara keseluruhan dapat diketahui bahwa rata-rata penilaian terhadap keseluruhan aspek bernilai sebesar 4,9 dengan kategori sangat praktis. Apabila dilihat dari masing-masing aspek maka dapat diketahui bahwa aspek yang paling praktis adalah prinsip reaksi produk dengan nilai rata-rata sebesar 5 dengan kategori sangat praktis.

4) Kevalidan Model pembelajaran Humanis religius dalam Pendidikan Karakter di Sekolah Dasar

Tingkat kesepakatan (reliabilitas) antar keempat penilai tersebut dapat dijelaskan dengan menghitung koefisien reliabilitas antarpenilai menggunakan koefisien Cohen's Kappa (к). Berikut hasil analisis statistik

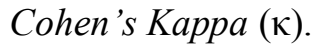

Tabel 3. Hasil Penilaian Setelah Implementasi

\begin{tabular}{lll}
\hline \multicolumn{1}{c}{ Perangkat } & $\begin{array}{c}\text { Koefisien } \\
\text { Cohen's Kappa } \\
(\boldsymbol{\kappa})\end{array}$ & $\begin{array}{c}\text { Kategori } \\
\text { Kesepakatan }\end{array}$ \\
\hline $\begin{array}{l}\text { Buku Panduan } \\
\text { Produk }\end{array}$ & 0,755 & Sangat baik \\
Instrumen Penilaian & 0,733 & Sangat baik \\
\hline
\end{tabular}

Keterangan Penilaian:

$\kappa<0.40 \quad$ : Kurang

$0.40<\kappa<0.75$ : Baik

$\kappa>0.75 \quad$ : Sangat baik

Tabel di atas memperlihatkan bahwa model pembelajaran humanis religius dalam pendidikan karakter dan perangkat penilaiannya yang dikembangkan memiliki kategori kevalidan yang tergolong sangat baik dan reliabel setelah implementasi.

b. Tanggapan peserta didik terhadap Model pembelajaran Humanis religius Dalam Pendidikan Karakter di Sekolah Dasar

Pada tahap implementasi, respon peserta didik juga dilakukan penilaian terhadap respon peserta didik. Hasil penilaian terhadap respon peserta didik pada tahap implementasi dapat dilihat pada tabel berikut.

Tabel 4. Hasil Penilaian Respon Peserta Didik

\begin{tabular}{lcccc}
\hline Pengukuran & SD1 & SD1 & Rerata & Kategori \\
\hline $\begin{array}{l}\text { Respon peserta } \\
\text { didik terhadap }\end{array}$ & 4.7 & 4.8 & 4.8 & $\begin{array}{c}\text { Sangat } \\
\text { Paik }\end{array}$ \\
\hline
\end{tabular}

Tabel di atas menunjukkan bahwa respon peserta didik terhadap model pembelajaran humanis religius dalam pendidikan karakter di sekolah dasar menjadi sangat baik. Hasil penilaian terhadap respon peserta didik menunjukkan bahwa model pembelajaran humanis religius telah cukup baik diterapkan pada pendidikan karakter di sekolah dasar. Hasil pengamatan keterlaksanaan model pembelajaran humanis religius dalam pendidikan karakter di sekolah dasar, pada uji coba terbatas maupun pada implementasi (uji coba diperluas) menunjukkan bahwa tingkat keterlaksanaan tahapan-tahapan pembelajaran di 
kelas sangat baik. Dengan demikian dapat disimpulkan bahwa model pembelajaran humanis religius dalam pendidikan karakter sangat praktis dan dapat digunakan di sekolah dasar.

\section{Revisi Produk}

Setelah melalui berbagai tahap dalam proses pengembangan, mulai dari expert judgment, FGD, penilaian kelompok kecil, dan penilaian akhir diperoleh draft produk akhir model pembelajaran humanis religius dalam pendidikan karakter di sekolah dasar. Data yang diperoleh dari hasil expert judgment, FGD, ujicoba terbatas menjadi dasar untuk melakukan revisi model pembelajaran humanis religius dalam pendidikan karakter di sekolah dasar yang dikembangkan beserta instrumen penilaiannya secara keseluruhan. Produk ini telah terbukti valid, efektif, dan praktis, baik dari segi isi, bahasa, serta tampilan yang merupakan satu kesatuan. Berdasarkan penilaian dari para ahli dan praktisi pendidikan, terdapat beberapa faktor yang menjadi kekuatan model pembelajaran humanis religius dalam pendidikan karakter di sekolah dasar.

Temuan-temuan dari pelaksanaan uji coba dan respon yang diberikan praktisi pendidikan, digunakan untuk melakukan revisi model pembelajaran humanis religius dalam pendidikan karakter di sekolah dasar. Setelah ujicoba terbatas, model pembelajaran humanis religius dalam pendidikan karakter di sekolah dasar beserta perangkat instrumen penilaiannya yang telah direvisi diujikan kembali pada implementasi dengan melibatkan peserta didik dan sekolah dasar yang lebih banyak. Secara umum, masukan yang menjadi saran perbaikan dalam penerapan model pembelajaran humanis religius dalam pendidikan karakter di sekolah dasar telah digunakan peneliti dalam melakukan revisi produk. Catatan-catatan revisi tersebut merupakan catatan revisi terhadap produk selama proses pengembangan, dari validasi produk sampai dengan tahap implementasi.

Dalam pengembangan produk, telah dilakukan revisi sesuai dengan saran-saran revisi dari para ahli maupun praktisi pendidikan sebagaimana catatan di atas. Setelah melakukan revisi sesuai dengan masukan dan saran dari ahli dan praktisi pendidikan, produk telah divalidasi pada akhir pelaksanaan implementasi model pembelajaran humanis religius dalam pendidikan karakter di sekolah dasar. Validasi akhir dilakukan dengan 4 orang praktisi pendidikan. Hasil implementasi telah menunjukkan bahwa model pembelajaran humanis religius dalam pendidikan karakter di sekolah dasar telah memenuhi kategori valid, efektif, dan praktis sehingga tidak perlu lagi diujicobakan. Hasil rekomendasi dan saran-saran untuk revisi selama proses pengembangan telah menghasilkan produk akhir berupa pembelajaran humanis religius dalam pendidikan karakter di sekolah dasar.

\section{Kajian Produk Akhir}

Pendidikan karakter pada saat ini merupakan isu utama dalam dunia pendidikan di Indonesia. Namun demikian, pendidikan karakter masih menjadi sebatas wacana. Masih banyak permasalahan yang terkait dengan pelaksanaan pendidikan karakter. Pelaksanaan pendidikan karakter yang terintegrasi pada seluruh mata pelajaran dianggap sulit, terutama pada sekolah dasar sehingga tidak dilaksanakan. Pelaksanaan pendidikan karakter seringkali masih dianggap sebagai kewajiban dari mata pelajaran tertentu saja, seperti halnya Pendidikan Kewarganegaraan dan Pendidikan Agama.

Berdasarkan landasan tersebut, sebagai upaya untuk menanamkan karakter pada peserta didik sekolah dasar diperlukan suatu model pembelajaran yang dapat mengintegrasikan pendidikan karakter pada seluruh mata pelajaran. Model pembelajaran yang dikembangkan adalah model pembelajaran humanis religius. Dalam hal ini, model pembelajaran humanis religius yang dikembangkan adalah model pembelajaran yang dapat diterapkan di kelas pada seluruh mata pelajaran secara berkesinambungan. Hal ini telah dibuktikan melalui implementasi model pembelajaran pada saat pelaksanaan penelitian.

Proses pengembangan dilaksanakan melalui beberapa fase, yaitu investigasi awal untuk mengetahui permasalahan dan konsepkonsep teori yang mendasari pengembangan pembelajaran humanis religius, fase desain, dan fase realisasi atau konstruksi produk. Fase-fase ini menghasilkan sebuah draft awal model pembelajaran dalam pendidikan karakter di sekolah dasar. Draft awal kemudian dievaluasi melalui expert judgment, FGD, uji coba terbatas, dan implementasi produk. Ta- 
hapan-tahapan tersebut menghasilkan draft akhir pembelajaran humanis religius dalam pendidikan karakter di sekolah dasar yang memenuhi kategori valid, efektif, dan praktis. Tahap implementasi sekaligus menjadi tindakan sosialisasi terhadap hasil pengembangan sehingga produk diharapkan sudah dapat diterapkan di sekolah. Hasil akhir dari produk pengembangan ini adalah model pembelajaran humanis religius dalam pendidikan karakter di sekolah dasar dalam bentuk buku panduan produk, serta perangkat instrumen penilaian pembelajaran dan output pendidikan karakter.

Dalam fase investigasi awal ditemukan sejumlah permasalahan terkait dengan model pembelajaran dan pendidikan karakter yang dilaksanakan di sekolah dasar. Fase investigasi awal juga menghasilkan sejumlah nilainilai karakter yang dapat dikembangkan dalam pendidikan di sekolah dasar. Hasil investigasi awal tersebut dirumuskan menjadi produk awal pembelajaran humanis religius yang tepat dan sesuai dengan karakteristik pendidikan karakter di sekolah dasar. Selanjutnya, produk awal tersebut divalidasi oleh ahli dan praktisi pendidikan.

Berdasarkan penilaian (validasi) ahli dan praktisi pendidikan, model pembelajaran humanis religius awal dinyatakan dapat digunakan dalam pendidikan karakter di sekolah dasar dengan sedikit revisi. Begitu pula halnya dengan perangkat instrumen penilaian yang dapat digunakan dengan revisi. Selanjutnya, penilaian terhadap model pembelajaran humansi dalam pendidikan karakter di sekolah dasar dilakukan sebanyak 3 kali, yaitu praujicoba terbatas melalui expert judgment dan FGD, setelah ujicoba terbatas, dan setelah implementasi. Expert judgment dilakukan oleh para ahli di bidang pendidikan humanis religius dan bidang pembelajaran, sedangkan FGD dilakukan dengan praktisi pendidikan. Penilaian pada saat setelah ujicoba terbatas dan setelah implementasi dilakukan oleh praktisi lapangan.

Setelah melalui ujicoba terbatas dan implementasi, maka hasil pengembangan berupa model pembelajaran humanis religius dalam pendidikan karakter di sekolah dasar dinyatakan memenuhi kategori valid, efektif, dan praktis. Dengan demikian, dapat disimpulkan bahwa model pembelajaran humanis religius dalam pendidikan karakter di sekolah dasar merupakan model pembelajaran yang me- miliki kualitas baik untuk diterapkan pada pembelajaran di kelas pada sekolah dasar. Hasil analisis kevalidan menunjukkan bahwa semua validator menyatakan bahwa model pembelajaran humanis religius dalam pendidikan karakter di sekolah dasar beserta perangkatnya dibangun atas landasan berpikir yang rasional dengan teori pendukung yang kuat dan relevan.

Analisis keefektifan model pembelajaran humanis religius dalam pendidikan karakter menunjukkan bahwa model pembelajaran humanis religius memenuhi kategori sangat efektif. Tingkat keefektifan dapat dilihat dari perilaku mengajar guru, kepribadian guru, respon peserta didik terhadap pembelajaran, proses pembelajaran, output hasil pembelajaran, fasilitas dan media pembelajaran yang tersedia, serta penilaian terhadap aspek-aspek efektifitas produk. Dari hasil analisis keefektifan disimpulkan bahwa model pembelajaran humanis religius dalam pendidikan karakter sangat efektif digunakan di jenjang sekolah dasar. Berdasarkan ujicoba dan implementasi yang dilaksanakan dapat diketahui bahwa model pembelajaran humanis religius dalam pendidikan karakter di sekolah dasar dapat berfungsi dengan baik untuk menanamkan karakter positif dalam diri peserta didik di sekolah dasar.

Keterbatasan Penelitian

Beberapa faktor yang menjadi keterbatasan dalam pelaksanaan penelitian ini adalah sebagai berikut.

1. Penelitian ini dilaksanakan dengan melibatkan 3 sekolah dasar yang terdapat di Kabupaten Bantul, yaitu SD Baturetno, SD Jomblangan, dan SD Jaranan. Keterbatasan lokasi penelitian dapat mengakibatkan hasil penelitian belum dapat digeneralisasi pada populasi lain yang memiliki karakteristik berbeda dengan lokasi penelitian.

2. Pengembangan model telah dilaksanakan sampai dengan tahap implementasi, namun demikian belum ada sosialisasi lebih lanjut terhadap hasil pengembangan. Keterbatasan waktu dalam melakukan sosialisasi mengakibatkan tidak adanya kepastian mengenai pemahaman guru terhadap model pembelajaran humanis religius dalam pendidikan karakter di sekolah dasar. 
3. Nilai-nilai karakter positif yang dikembangkan hanya terbatas pada 5 nilai karakter yang dapat diterapkan pada sekolah dasar. Oleh karena itu, diharapkan ada pengembangan lebih lanjut dengan mengembagkan nilai-nilai karakter lainnya.

\section{SIMPULAN DAN SARAN}

\section{Simpulan}

Berdasarkan hasil penelitian menunjukkan bahwa: (1) pengembangan model diawali dengan studi pendahuluan, studi pengembangan, dan implementasi yang kemudian menghasilkan perangkat model pembelajaran humanis religius dalam pendidikan karakter di sekolah dasar berupa buku panduan model pembelajaran, perangkat penilaian, dan instrumen pengembangan model pembelajaran untuk menerapkan nilai karakter religius, jujur, toleransi, disiplin, dan kerja keras, (2) model humanis religius dalam pendidikan karakter di sekolah dasar menunjukkan tingkat keterlaksanaan yang tergolong baik, memenuhi kriteria sangat efektif, sangat praktis, dan valid karena disusun berdasarkan landasan berpikir yang rasional dengan teori pendukung yang kuat dan relevan, (3) model pembelajaran humanis religius dalam pendidikan karakter yang dikembangkan efektif untuk digunakan dalam pendidikan karakter di sekolah dasar, dan (4) peserta didik memiliki respon yang sangat positif terhadap model pembelajaran humanis religius dalam pendidikan karakter di sekolah dasar.

\section{Saran Pemanfaatan Produk}

Model pembelajaran yang dikembangkan untuk menanamkan karakter positif dalam diri peserta didik di sekolah dasar adalah model pembelajaran humanis religius. Pengembangan model ini terbatas hanya sampai implementasi, dan belum ada sosialisasi lebih lanjut. Oleh karena itu, diharapkan pada guru dan praktisi pendidikan untuk melakukan menerapkan model pembelajaran humanis religius dalam pendidikan karakter di sekolah dasar.

Penerapan model pembelajaran humanis religius dalam pendidikan karakter di sekolah dasar tergolong efektif dan praktis digunakan untuk menanamkan nilai-nilai karakter positif dalam duri siswa. Oleh sebab itu, disarankan kepada guru di sekolah dasar yang menggunakan model pembelajaran humanis religius dalam pendidikan karakter di sekolah dasar mampu melakukan pengembangan terhadap nilai karakter yang diterapkan. Dalam hal ini, nilai karakter yang diterapkan tidak dibatasi pada nilai karakter yang digunakan dalam penelitian ini saja, akan tetapi dapat dikembangkan lagi.

Dalam melaksanakan penerapan model pembelajaran humanis dalam pendidikan karakter di sekolah dasar, Kepala Sekolah maupun guru sebaiknya mempelajari dan memahami buku pedoman pembelajaran dan evaluasi yang merupakan bagian dari pengembangan produk model pembelajaran humanis dalam pendidikan karakter di sekolah dasar secara seksama. Hal ini perlu dilakukan agar Kepala Sekolah dan guru benar-benar memahami cara penerapan pembelajaran humanis.

\section{DAFTAR PUSTAKA}

Adhiatera, T. (2008). Perjalanan Spiritual Seorang Kristen Sekuler. Jakarta: BPK Gunung Mulia.

Albertus, D. K. (2007). Pendidikan Karakter, Strategi Mendidikan Anak di Zaman Global. Jakarta: Grasindo.

Albertus, D. K. (2009). Pendidik Karakter di Zaman Keblinger, Mengembangkan Visi Guru sebagai Pelaku Perubahan Pendidik Karakter. Jakarta: Grasindo.

Amin, H. (2011). Aktualisasi Humanisme Religius Menuju Humanisme Spiritual (Perspektif Filsafat Agama). Laporan Hasil Penelitian. IAIA Ar-Raniry, Banda Aceh.

Borg, W. R. \& Gall, M. D. (1989). Educational Research: An Introduction. New York: Longman.

Comer, R. \& Gould, E. (2012). Psychology Around Us. New York: Halsted Press, Division John Wiley \& Sons, Inc.

Dewey, J., terj. Zainuddin, A. R. (1998). Budaya dan Kebebasan. Jakarta: Yayasan Obor Indonesia.

Leonard, D. C. (2002). Learning Theories: A to Z. Greenwood: ABC-CLIO. 
Mumpuniarti. (2010). Perspektif Humanis Religius dalam Pendidikan Inklusif. Jurnal Pendidikan Khusus Universitas Negeri Yogyakarta, 7, 2, 18-31.

Smith, L. \& Raeper, William, terj. Hadi, P. H. (2000). Ide-Ide: Filsafat dan Agama, Dulu dan Sekarang. Yogyakarta: Kanisius.

Sobur, A. (2003). Psikologi Umum. Bandung: Pustaka Setia.
Story, D. (1998). Christianity on the Offense: Responding to the Beliefs and Assumptions of Spiritual Seekers. Grand Rapids: Kregel Publication.

Triatmanto. (2010). Tantangan Implementasi Pendidikan Karakter di Sekolah. Cakrawala Pendidikan, Mei 2010, Th. XXIX, Edisi Khusus Dies Natalis UNY.

Veugelers, W. (2008). Education and Humanism: Linking Autonomy and Humanity. Switzerland: Sense Publishers. 